\title{
PEMAHAMAN SABDA PENGAMPUNAN ALLAH DALAM SAKRAMEN TOBAT MENURUT KARL RAHNER
}

\author{
E. Pranawa Dhatu Martasudjita*
}

\begin{abstract}
Abstrak: Dari pengamatan, tidak banyak tulisan teologis tentang sakramen tobat atau sakramen rekonsiliasi di lingkungan bahasa Indonesia selama ini. Begitu pula, ada kesan bahwa pemahaman umat Katolik mengenai sakramen tobat cukup terbatas. Dari sinilah artikel ini ingin memberi sumbangan pemikiran teologis melalui kekayaan dan kedalaman pandangan teologis Karl Rahner mengenai sakramen tobat. Dari penelitian penulis, sabda pengampunan Allah menjadi inti pemikiran Rahner tentang sakramen tobat. Dengan metode teologi transendental sebagaimana dikembangkan oleh Karl Rahner, penulis mengupas secara kritis pemahaman sabda pengampunan Allah melalui alur pemikiran sakramental Rahner. Rahner berpendapat bahwa manusia memiliki pengalaman dasar akan dosa-kesalahan yang tak dapat dihapus oleh diri sendiri, dan justru karena itulah manusia senantiasa mendambakan sabda pengampunan Allah sebagai pemberian diri Allah (Selbstmitteilung Gottes) yang berpuncak pada wafat dan kebangkitan Kristus. Melalui Gereja, sabda pengampunan Allah itu dihadirkan melalui aneka macam bentuk, sedangkan yang khusus dan istimewa melalui sakramen tobat. Tulisan ini ditutup dengan penyampaian poin-poin relevansi pandangan Rahner tersebut bagi Gereja sekarang ini.
\end{abstract}

Kata-kata kunci: Sabda pengampunan Allah, sakramen tobat, sakramen rekonsiliasi, teologi sakramental, teologi transendental, belas kasih Allah.

Abstract: Theology of Sacrament of reconciliation has not been widely written and developed in Indonesia, and therefore the general understanding among the faithful. This article is to contribute, particularly by presenting Karl Rahner's theology on the sacrament 
of reconciliation. Rahner focused on the forgiving word of God. Employing his transcendental method, this article is presenting a critical study on the understanding of Rahner's forgiving word of God as well as his sacramental theology. Rahner showed that human beings themselves aware and know of their experience of sin or guilt and could not just get out of it, and because of that human beings themselves are longing for forgiveness and God's forgiving word (Selbstmitteilung Gottes) revealed per exellentiam in the death and resurrection of Christ. Disciples of Christ gathered as people of God or church make present God's forgiving word here and now in various forms, yet especially in the sacrament of reconciliation. The article shall conclude with points of relevance for the church today.

Keywords: God's forgiving word, sacrament of penance, sacrament of reconciliation, sacramental theology, transcendental theology, mercy of God.

\section{PENDAHULUAN}

Tidak salah kiranya jika dikatakan bahwa umat Katolik di Indonesia masih rajin menerima sakramen tobat hingga saat ini. Memang hingga sekarang ini belum ada penelitian ilmiah yang serius tentang pemahaman dan penghayatan sakramen tobat pada umat Katolik di Indonesia. ${ }^{1}$ Tentu saja mesti diakui dan disadari bahwa kehidupan dan praktek penghayatan iman umat Katolik (antar masing-masing Keuskupan) di Indonesia tidak berciri homogen, alias sangat beragam dan dapat berbeda. ${ }^{2}$ Tanpa

* E. Pranawa Dhatu Martasudjita, Fakultas Teologi, Universitas Sanata Dharma, Jl. Kaliurang Km 7, Yogyakarta 55011. E-mail:epd-martasudjita@usd.ac.id.

1 St. Suratman Gitowiratmo dan Francis Purwanto pernah mengadakan penelitian tentang pelayanan pastoral Gereja di Keuskupan Agung Semarang dengan mengambil sampel 10 Paroki. Dalam kaitannya dengan sakramen tobat, penelitian ini cuma menyebut persepsi umat terhadap pelayanan imam dalam sakramen pengampunan. Dari hasil penelitian, umat menilai tinggi pelayanan para imam dalam memberikan sakramen tobat $(94,6 \%)$. Tetapi tentang pemahaman dan penghayatan sakramen tobat sendiri oleh umat tidak disebut dalam penelitian ini. Lih. Relevansi Pelayanan Pastoral Gereja Keuskupan Agung Semarang dalam Konteks Budaya Hidup Sekularistik, Yogyakarta: Kanisius - Pusat Penelitian dan Pelatihan Teologi Kontekstual Fakultas Teologi - Universitas Sanata Dharma, 2010, hlm. 42.

2 Pluralitas keadaan kehidupan umat Katolik di Keuskupan-keuskupan di Indonesia dapat dibaca dalam V. Indra Sanjaya dan F. Purwanto, Mozaik Gereja Katolik Indonesia. 50 Tahun Pasca Konsili Vatikan II, Yogyakarta: Kanisius, 2013. 
mengabaikan keberagaman dan perbedaan ini, di banyak Keuskupan dapat kita saksikan dengan mudah bahwa pada masa prapaskah dan masa adven masih ada banyak warga Katolik yang antri untuk menerima sakramen tobat. Frekuensi rata-rata kebanyakan umat Katolik yang menerima sakramen tobat adalah dua kali setahun. Para biarawan dan biarawati, ataupun mungkin para imam, menerima sakramen tobat dapat lebih dari dua kali setahun.

Pertanyaannya adalah apakah praktek penerimaan sakramen tobat pada umat Katolik di Indonesia yang disebut "rajin" itu memang sudah didorong oleh pemahaman yang mendalam dan mendasar atas sakramen tobat ataukah sekedar kebiasaan atau rutinitas saja. Sebagai gambaran saja, ada sebuah penelitian yang terbatas di kalangan para mahasiswa di Yogyakarta, yang hasilnya menunjukkan bahwa banyak orang yang menerima sakramen tobat karena kebiasaan daripada pemahaman yang mendalam. ${ }^{3}$ Ketika Paus Fransiskus memaklumkan Tahun Kerahiman Allah pada tahun 2015 - 2016, sakramen tobat digalakkan di manamana. Saat itu ada cukup banyak katekese dan pendalaman yang diselenggarakan di tengah umat Katolik. ${ }^{4}$ Akan tetapi katekese itu lebih berupa pertemuan dan bila ada tulisan pun lebih bersifat populer. Harus diakui bahwa tidak banyak tulisan ilmiah mengenai sakramen tobat dalam bahasa Indonesia hingga saat ini. Dua latar belakang inilah, yaitu kurangnya pemahaman yang mendalam umat Katolik terhadap sakramen tobat dan amat sedikitnya tulisan ilmiah tentang sakramen tobat, yang

3 Penelitian dibuat oleh Hedwigis Dian Permatasari dalam rangka skripsinya tentang pengaruh sakramen tobat terhadap tugas penghayatan pewartaan mahasiswa Program Studi Ilmu Pendidikan Kekhususan Pendidikan Agama Katolik Universitas Sanata Dharma Yogyakarta. Peneliti menemukan bahwa para responden merayakan sakramen tobat 2 kali setahun yakni masa prapaskah dan adven dengan alasan kebiasaan saja, dan frekwensi penerimaan sakramen ini tidak lebih sering karena responden merasa malu dengan imam dan tidak adanya rasa bersalah atau berdosa. Peneliti menyebutkan bahwa penyebab rasa malu kepada imam itu dikarenakan oleh belum baiknya pemahaman responden terhadap makna sakramen tobat. Lih. Pengaruh Penghayatan Sakramen Tobat terhadap Penghayatan Tugas Pewartaan Mahasiswa Program Studi Ilmu Pendidikan Kekhususan Pendidikan Agama Katolik USD Yogyakarta, pdf-skripsi 2009, pp. 78-79. https://repository.usd.ac.id/22630/2/051124002_Full.pdf

4 Salah satu pembicaraan serius mengenai sakramen tobat diadakan oleh Asian Liturgy Forum (ALF) yang diikuti oleh para pakar dan pemerhati liturgi se Asia, di Denpasar tanggal 11-14 Oktober 2016. Berita di: http://www.hidupkatolik. com/2016/10/26/1768/alf-bahas-sakramen-tobat/ 
menjadi alasan tulisan artikel ini.

Penulis mengambil fokus pada pendalaman makna sakramen tobat yang perlu dipahami oleh umat beriman pada masa kini. Di sini penulis mengangkat pandangan Karl Rahner SJ (1904 - 1984) mengenai sakramen tobat. Karl Rahner memang sudah meninggal 35 tahun yang lalu, akan tetapi pandangan teologisnya yang tersebar di banyak sekali tulisan ${ }^{5}$ masih bergema kuat dalam diskusi teologis di tingkat internasional. ${ }^{6}$ Sumbangannya sebagai salah satu peritus (ahli) dalam Konsili Vatikan II (1962-1965) tidak perlu diragukan. ${ }^{7}$ Tulisan Karl Rahner mengenai tema sakramen tobat tergolong sangat luas dan mendalam. ${ }^{8}$ Dari studi penelitian ini, di satu pihak penulis mengagumi keluasan dan kemendalaman Karl Rahner dalam mengupas sakramen tobat, di lain pihak penulis merasa tidak mudah untuk membedah dan menyederhanakan gagasan Karl Rahner tentang sakramen tobat. Dari begitu banyak tulisan dan pandangan Karl Rahner tentang sakramen tobat, penulis menemukan gagasan sabda pengampunan Allah sebagai inti pandangannya mengenai sakramen tobat ini.

Kami mendekati pemahaman Karl Rahner atas sabda pengampunan Allah ini dengan analisa kritis terhadap berbagai tulisan Rahner menge-

5 Menurut Pusat Arsip Karl Rahner di Munich, Jerman, ada sekitar 4000 judul tulisan Karl Rahner dalam aneka bentuk: buku, artikel, makalah ceramah, dan berbagai tulisan yang sudah ataupun belum dipublikasikan. Dapat dilihat di https:/ / www.karlrahner-archiv.de/das-archiv/bestaende

6 Dr. Muhammad Shahid Habib, seorang asisten profesor di Lahore Garrison University, Lahore, Pakistan, menulis artikel yang menarik: "Karl Rahner's Thought and His Contribution to the Christian Theology and Philosophy in 20th Century." Di sini Muhammad Shahid Habib mengakui Karl Rahner sebagai salah satu teolog besar abad XX yang pandangannya sangat mempengaruhi filsafat dan teologi kristiani di seluruh dunia. Lihat dalam International Journal of Philosophy and Social-Psychological Sciences 2016, Vol. 2 (issue 3), pp. 91-96, tersedia di at www.sciarena.com.

7 Seperti disebut oleh Karen Kilby yang berkata: “Dan dalam hampir semua pemberitaan (tentang Konsili Vatikan II) kecuali dalam laporannya sendiri, ia (Karl Rahner) disebut-sebut sebagai salah seorang yang berpengaruh dalam Konsili tersebut." K. Kilby, Karl Rahner, hlm. 11.

8 Ada banyak tulisan Karl Rahner mengenai sakramen tobat, antara lain: satu seri Schriften zur Theologie sendiri (bab XI) yang membicarakan sejarah sakramen tobat pada masa awal Gereja (512 halaman), beberapa artikel lepas di Schriften zur Theologie: bab II, SS.143-183; II, SS. 279-297; III, SS. 211-225; III, SS. 227-245; VI, SS. 238-261; VI, SS. 262-267; VIII, SS. 447-487; XVI, SS. 418-437, Sacramentum Mundi I, SS. 655-679, dan tentu saja satu buku kecil berjudul: Über die Sakramente der Kirche: Meditationen. 
nai sakramen tobat dalam terang metode teologi transendental. Rahner memang dipandang sebagai teolog yang paling menonjol dan berpengaruh dalam mengembangkan pandangan teologisnya melalui metode dan pendekatan teologi transendental. ${ }^{9}$ Pendekatan teologi transendental ini sebenarnya merupakan penerimaan konsepsi filsafat transendental (seperti dikembangkan oleh Kant) ke dalam pemikiran Katolik sejak Joseph Maréchal. ${ }^{10}$ Karl Rahner sendiri menggunakan pendekatan teologi transendental dari pengaruh J. Maréchal ini dan ditambah dari pengaruh filsuf Martin Heidegger untuk hampir semua topik teologis tulisannya. ${ }^{11}$ Ciri khas teologi transendental Rahner adalah pendekatannya terhadap topik-topik iman kristiani dengan menggunakan titik pangkal antropologis, yakni analisanya terhadap pengalaman manusiawi tentang pengetahuan dan kebebasan sebagai suatu pengalaman transendentalitas yang mutlak dan tak terbatas. ${ }^{12}$ Pengalaman transendentalitas ini menentukan dan mengungkapkan sifat historis pribadi manusia sebagai yang secara radikal terbuka terhadap Yang Transenden, yakni Dia yang biasa kita sebut dengan Allah. ${ }^{13}$

Dengan memperhatikan pendekatan teologi transendental Karl Rahner, tulisan ini akan dimulai dengan membahas singkat makna rahmat sebagai pemberian diri Allah (Selbstmitteilung Gottes) dalam pengalaman manusia. ${ }^{14}$ Adapun teologi sakramental Karl Rahner sendiri dibangun berdasarkan konsep rahmat sebagai Selbsmitteiling Gottes. Di bagian ini kami tetap harus menyebut beberapa poin penting secara singkat pemikiran Karl Rahner mengenai teologi sakramentalnya sebagaimana pernah penulis bahas dalam tulisan lain. ${ }^{15}$ Selanjutnya perlu diuraikan

9 F. Schüssler Fiorenza, "Systematic Theology: Task and Methods", dalam F. Schüssler Fiorenza dan John P. Galvin (ed.), Systematic Theology. Roman Catholic Perspectives, Minneapolis: Fortress Press, 1991, pp. 38-39.

10 K. Rahner, "Transzendentaltheologie," dalam Sacramentum Mundi IV, S. 986.

11 F. Schüssler Fiorenza, "Systematic Theology: Task and Methods," p. 39.

12 F. Schüssler Fiorenza, "Systematic Theology: Task and Methods," p. 39.

13 F. Schüssler Fiorenza, "Systematic Theology: Task and Methods," p. 39.

14 Franz Gmainer-Pranzl, Glaube und Geschichte bei Karl Rahner und Gerhard Ebeling. Ein Vergleich transzendentaler und hermeneutischer Theologie, Innsbruck-Wien: Tyrolia Verlag, 1996, SS. 23-24.

15 Lihat tulisan kami: "Pemikiran Sakramental Karl Rahner dan Aktualisasinya," dalam Melintas, vol. 20 no 63 (Desember 2004-Maret 2005), hlm. 75-93; dan "Hubungan Ekaristi dan Hidup Sehari-hari dalam Teologi Sakramental Karl Rahner," dalam 
pandangan Karl Rahner mengenai pengalaman dasar manusia atas dosa dan kesalahan yang menjadi titik pangkal pembahasan Rahner tentang sakramen tobat. Misteri manusia berhadapan dengan dosa dan kesalahan yang tak terelakkan menempatkan manusia pada Misteri Allah dan belas kasih-Nya. Dalam pewahyuan Yesus Kristus, manusia menemukan bentuk perwujudan belas kasih dan pengampunan Allah secara historis dan manusiawi menurut tingkat puncak dan kepadatannya. Itulah sabda pengampunan Allah yang sebenarnya menjadi kerinduan setiap manusia. Melalui Gereja dan berbagai bentuk pengungkapan dan pelaksanaannya, tetapi terutama melalui sakramen tobat orang dapat beroleh sabda pengampunan Allah secara paling eksplisit dan manusiawisosial. Lalu akan dibahas beberapa segi sakramen tobat ini, seperti di manakah dasar kuasa Gereja untuk melayani sakramen tobat, perbedaan pengampunan dosa eksistensial dan sakramental, dan tanggapan Rahner tentang kemerosotan penerimaan sakramen tobat pada pasca-Vatikan II. Akhirnya, penulis ingin merefleksikan makna dan relevansi pandangan Rahner tentang sakramen tobat ini dalam konteks Gereja Katolik di Indonesia.

\section{PEMIKIRAN SAKRAMENTAL KARL RAHNER}

Pembahasan sakramen tobat dalam teologi Rahner tentu saja tidak dapat dilepaskan dari teologi sakramentalnya. Sementara itu pemikiran sakramental Karl Rahner berpangkal dari pandangan pokok teologisnya mengenai rahmat. Banyak orang yang memahami rahmat sebagai semacam "wahyu" atau "wangsit" atau sesuatu yang dijatuhkan dari langit dan kemudian seolah memasuki diri manusia. Di situ rahmat dipikirkan sebagai "sesuatu" yang diberikan oleh Tuhan secara cumacuma. Tidak demikian dengan Rahner, sebab ia memahami rahmat pertama-tama sebagai pemberian diri Allah sendiri (Selbsmitteilung Gottes) kepada umat manusia dan dunia. Dalam paham ini Allah bukan hanya sebagai pemberi tetapi juga sebagai yang diberikan. Ini berbeda dengan pandangan yang umum di atas, yakni tentang rahmat sebagai "sesuatu" yang diberikan oleh Allah, yang memang menjadi pandangan

Diskursus vol.12, no. 2, Oktober 2013, hlm. 278-301. 
yang sangat lazim sebagai warisan paham Skolastik. ${ }^{16}$ Dalam pandangan Rahner ini, rahmat adalah pemberian diri Allah sendiri, yang bermakna personal (karena diri Allah sendiri) dan dinamis (karena berupa pemberian diri atau yang dikomunikasikan). ${ }^{17}$

Pemberian diri Allah (Selbstmitteilung Gottes) dimengerti Rahner sebagai diri Allah sendiri dengan seluruh realitas dan adanya sebagai Allah, tetapi kini diberikan atau dikomunikasikan kepada manusia sedemikian rupa sehingga sungguh menjadi (bersifat) konstitutif secara paling dalam dan mendasar pada hakikat manusia. ${ }^{18}$ Karena itulah hakikat manusia hanya dapat dipahami dari sudut pemberian diri Allah. Seluruh eksistensi manusia, baik sejak awal mula, semasa hidup hingga akhir hidupnya ditopang dan didasari oleh pemberian diri Allah. ${ }^{19}$ Dengan ditopang dan didasari oleh pemberian diri Allah, manusia ada dan hidup melulu dalam hubungannya dengan Allah yang memberikan diri-Nya itu.

Pemberian diri Allah itu bukan sesuatu yang ditawarkan, seolaholah manusia bebas menerima atau menolak. Dalam teologi Rahner, rahmat sebagai pemberian diri Allah itu berciri intrinsik dan sudah ada, yakni melekat pada diri dan adanya manusia. ${ }^{20}$ Pemberian diri Allah kepada manusia dan dunia ini terlaksana dalam sejarah. Seluruh sejarah dunia dan umat manusia ditopang dan didasari oleh pemberian diri Allah itu. Di sinilah Rahner berbicara tentang sejarah keselamatan Allah yang bersifat universal atau umum. Artinya sejarah keselamatan Allah itu seluas atau koekstensif dengan seluruh sejarah dunia. ${ }^{21}$ Hanya saja pemberian diri Allah dalam rangka sejarah keselamatan universal itu masih berciri implisit dan belum memperoleh tanggapan yang jelas terungkap. Pemberian diri Allah yang mendasari dan menopang seluruh eksistensi hidup manusia dan dunia ini baru menjadi terungkap secara ekplisit dalam sejarah keselamatan khusus. Inilah sejarah keselamatan

16 Georg Kraus, "Gnade," dalam W. Beinert, Lexikon der katholischen Dogmatik, S. 207.

17 Kata bahasa Jerman Selbstmitteilung biasa diterjemahkan dengan kata bahasa Inggris Selfcommunication.

18 K. Rahner, Grundkurs des Glaubens, SS. 122-123.

19 K. Rahner, Über die Sakramente der Kirche. Meditation, SS. 13-14.

20 K. Rahner, Kirche und Sakrament, S. 16.

21 K. Rahner, Grundkurs des Glaubens, S. 147. 
Allah yang puncak perwujudannya terlaksana pada diri Yesus Kristus. Maksudnya, dalam diri Yesus Kristus yang tersalib dan bangkit, rahmat sebagai pemberian diri Allah, yang selalu ada di manapun dalam keseluruhan sejarah umat manusia, menjadi dapat ditangkap secara historis dan final.

Demikianlah sejarah keselamatan Allah mencapai puncak pelaksanaan atau realisasinya bagi sejarah dunia dan manusia dalam diri Yesus Kristus. ${ }^{22}$ Dalam diri Kristus terjadilah puncak secara final, pasti dan penuh kemenangan dari ungkapan pemberian diri Allah dan sekaligus tanggapan manusia atas pemberian diri Allah itu. ${ }^{23}$ Yesus adalah Allah - Manusia sekaligus yang dapat disebut sebagai Sakramen Induk (Ursakrament) karena Dia adalah Yang Ditandakan (diri Allah yang memberikan diri) dan Tanda yang kelihatan dan berdayaguna dari pemberian diri Allah itu, dan sekaligus penerimaannya melalui kemanusiaan-Nya yang historis dalam pribadi dan kesatuan. ${ }^{24}$ Sebagai Sakramen Induk, Yesus Kristus menjadi simbol real dari diri Allah sendiri yang memberikan diri-Nya kepada manusia. Kini Kristus menjadi patokan atau ukuran bagi semua pengalaman akan Allah, mana yang benar ataupun yang tidak benar. ${ }^{25}$

Pertanyaan selanjutnya ialah bagaimana Yesus Kristus yang menjadi kulminasi dan eksplisitasi pemberian diri Allah kepada manusia dan tanggapan manusia terhadap pemberian diri Allah itu dapat hadir di sepanjang sejarah dunia? Di sinilah kita menemukan Gereja yang oleh Rahner disebut sakramen dasar (Grundsakrament). Menurut Rahner, Gereja sebagai sakramen dasar menjadi tanda kehadiran Kristus secara historis-sosial di sepanjang sejarah, yakni sebagai tanda yang menghadirkan kemenangan Kristus yang menyelamatkan, bagi dunia yang mengalami dosa dan kegelapan, hingga mencapai kepenuhannya pada akhir zaman. ${ }^{26}$

22 K. Rahner, Über die Sakramente der Kirche. Meditation, S. 18.

23 K. Rahner, Grundkurs des Glaubens, S. 202.

24 K. Rahner, "Ekklesiologische Grundlegung," S. 139.

25 K. Rahner, Grundkurs des Glaubens, SS. 161-162.

26 K. Rahner, Über die Sakramente der Kirche. Meditation, S. 19. 
Dari sini kita sampai pada pengertian sakramen-sakramen, yang biasa kita kenal sebagai ketujuh sakramen. Pertanyaan yang mau dijawab Rahner ialah bagaimana pemberian diri Allah yang puncaknya terungkap dan terlaksana melalui Yesus Kristus dan yang kini dihadirkan dalam Gereja menjadi terungkap dan terlaksana pada diri masing-masing orang, kita semua, sepanjang sejarah? Justru disinilah tempat dan pengertian ketujuh sakramen yang menjadi ajaran resmi Gereja sejak Konsili Lyon II tahun $1274^{27}$ dan ditegaskan kembali dalam dogma oleh Konsili Trente tahun $1547 .{ }^{28}$ Dengan tetap berpegang pada ajaran dan tradisi Gereja Katolik mengenai tujuh sakramen, Rahner memahami sakramen-sakramen sebagai konkretisasi secara kelihatan dan historis dari janji Allah yang memberikan diri-Nya dan yang telah terlaksana secara final dan pasti dalam diri Yesus Kristus, sebagaimana disampaikan oleh Gereja sebagai sakramen dasar, dalam diri setiap orang. ${ }^{29}$ Di sini tampak bagaimana sakramen-sakramen dipikirkan Rahner secara kristologis (Kristus sebagai Ursakrament), eklesiologis (Gereja sebagai Grundsakrament), dan antropologis (konkretisasi secara historis pada setiap orang).

Menurut Rahner, sakramen-sakramen ini menjadi simbol-real dari peristiwa pemberian diri Allah yang secara puncak dan final terlaksana melalui Kristus, sebagaimana disampaikan oleh Gereja. Sakramensakramen itu benar-benar simbol tetapi simbol real atau simbol yang menghadirkan pemberian diri Allah melalui Kristus itu. Di samping itu ketujuh sakramen juga melaksanakan secara aktual dan berdaya ubah pada diri setiap orang yang menerima sakramen apa yang dilambangkan itu, yakni pemberian diri Allah melalui Kristus, sebagaimana dilayankan oleh Gereja. Dari penekanan bahwa sakramen-sakramen itu sungguh simbol real yang mengungkapkan dan sekaligus melaksanakan apa yang dilambangkan, Rahner tetap bergerak pada ajaran Gereja mengenai dayaguna sakramen-sakramen, baik secara opus operatum maupun opus operantis. Sakramen-sakramen itu berdayaguna secara opus operatum, dalam arti: Allah sendiri yang bersabda dan berkarya dalam perayaan

27 DS 860/NR 928.

28 DS 1601/NR 506.

29 Karl Rahner, Grundkurs des Glaubens, S. 397. 
sakramen itu; dan sakramen-sakramen itu berdayaguna secara opus operantis, dalam arti: diperlukannya tanggapan positif dan terbuka dari pihak manusia yang merayakan sakramen-sakramen itu. ${ }^{30}$ Karl Rahner merumuskan bahwa sakramen-sakramen tidak lain adalah Sabda Alah yang berdayaguna pada manusia, dalam mana Allah sendiri memberikan diri-Nya (sehingga menyelamatkan manusia), dan dalam mana manusia tetap diberi kebebasan untuk menerima pemberian diri Allah itu secara konkret. $^{31}$

\section{PENGALAMAN DASAR MANUSIA ATAS DOSA DAN KESALAHAN}

Ketika Rahner membahas sakramen tobat atau sakramen pengampunan dosa, ia selalu mengawalinya dengan menggali terlebih dahulu pengalaman dasar manusia sebagai pribadi yang rapuh dan terancam oleh dosa dan kesalahan. ${ }^{32}$ Untuk membicarakan soal dosa dan kesalahan, Rahner bertolak dari pemahaman manusia yang dari hakikatnya adalah pribadi yang bertanggungjawab dalam kebebasan (Verantwortung in Freiheit). ${ }^{33}$ Jalan pikiran Rahner sebagai berikut: adanya Injil atau warta kristiani mengenai kabar keselamatan Allah melalui Yesus Kristus yang terlaksana dalam sejarah pasti memiliki pengandaian bahwa manusia itu harus suatu pribadi, sebuah subjek. ${ }^{34}$ Mengapa? Karena suatu relasi dengan Allah ataupun suatu sejarah keselamatan yang sungguh-sungguh dialogis antara Allah dan manusia, apalagi dalam pengertian Rahner: isi keselamatan yang adalah pemberian diri Allah, tentu mengandaikan manusia sebagai pribadi dan subjek. Sebagai suatu pribadi dan subjek, manusia menyadari siapa dirinya dan sekaligus sadar bahwa diri dan eksistensinya adalah hasil dari sesuatu yang bukan dirinya sendiri. Justru di sinilah Rahner berpendapat bahwa manusia itu adalah hakikat yang transenden (das Wesen der Transzendenz). ${ }^{35}$

30 Karl Rahner, Grundkurs des Glaubens, S. 399.

31 Karl Rahner, Grundkurs des Glaubens, S. 400.

32 K. Rahner, Über die Sakramente der Kirche. Meditation, S. 85; Grundkurs des Glaubens, S. 405.

33 Persisnya Rahner menyebut manusia sebagai das Wesen der Verantwortung in Freiheit, dalam Grundkurs des Glaubens, S. 405.

34 Karl Rahner, Grundkurs des Glaubens, S. 37.

35 Karl Rahner, Grundkurs des Glaubens, S. 42. 
Manusia sebagai hakikat yang transenden berarti bahwa manusia mempunyai kemampuan untuk mentransendensi diri, artinya: mengalami hal yang melampaui dirinya. Justru di sinilah menurut Karl Rahner, manusia selalu memiliki apa yang disebut dengan pengalaman transendental. Pengalaman transendental menunjuk pada pengalaman kesadaran diri yang bersifat subjektif dan atematis tentang sesuatu yang hadir sebagai yang tak dimengerti dalam setiap tindakan pengenalan. ${ }^{36}$ Sederhananya, pengalaman transendental itu merupakan pengalaman manusia akan realitas yang melampaui dirinya, yang anonim dan tak terpahami, yaitu realitas yang biasa kita sebut dengan Allah. Itulah pengalaman dasar manusia sebagai pengalaman keterbukaan kepada Yang Transenden, yang melampaui dirinya, yang disebut eksistensi adikodrati (ÜbernatürlichesExistenial). ${ }^{37}$ Eksistensi adikodrati dipahami Rahner bukan berpangkal dari sisi manusia yang seakan-akan dari dirinya sendiri berinisiatif untuk mencari Allah, tetapi seperti telah disebutkan di atas, justru karena bertolak dari pemberian diri Allah kepada manusia dan dunia sebagai peristiwa atau realitas yang sudah diberikan, sudah ada, dan melekat pada hakikat eksistensi manusia. Pemberian diri Allah yang telah menopang dan mendasari seluruh eksistensi hidup manusia inilah, entah disadari atau tidak, yang membuat manusia menjadi terbuka atau bahkan mencari Allah.

Eksistensi adikodrati manusia berkat pemberian diri Allah itu bukan hanya membuat manusia terbuka kepada Allah, tetapi juga membuat manusia memiliki kesanggupan dasar untuk bertindak secara bebas dan bertanggungjawab. Di sinilah Rahner berbicara tentang pengalaman transendental kebebasan, atau dapat disingkat dengan kebebasan transendental. ${ }^{38}$ Dengan metode teologi transendental, Rahner membedakan struktur pengalaman dan pengenalan manusia yang berupa pengalaman transendental seperti yang sudah disebut beberapa kali di atas dan pengalaman kategorial. Pengalaman transendental sebagai keterbukaan akan Yang Transenden ini merupakan pengalaman dasar

36 Karl Rahner, Grundkurs des Glaubens, S. 31.

37 K. Rahner, Grundkurs des Glaubens, SS. 132-139.

38 Karl Rahner, Grundkurs des Glaubens, S. 103. 
yang menopang, mendasari, menjiwai atau ada di dalam pengalaman kategorial. Pengalaman kategorial ini adalah pengalaman indrawi manusiawi yang konkret dan fragmentaris, yang kita alami sehari-hari, seperti belajar, membaca, mencuci, memasak, berdoa, tidur, makan, dan seterusnya. Di balik pengalaman kategorial ini hadir atau ada pengalaman transendental yang dimungkinkan oleh pemberian diri Allah itu.

Rahner memikirkan kebebasan transendental sebagai kebebasan dasar yang dimiliki manusia secara intrinsik dan melekat pada hakikatnya, dan itu dimungkinkan karena pemberian diri Allah yang sudah diberikan kepada manusia. Nah, pengalaman kebebasan sehari-hari seperti misalnya: bebas untuk makan soto atau nasi goreng, bebas memilih pasangan hidup, bebas memakai baju mana untuk hari ini, termasuk bebas untuk melakukan yang baik dan yang tidak baik kepada sesama, dan sebagainya itu, disebut kebebasan kategorial. Macam-macam bentuk kebebasan konkret yang disebut kebebasan kategorial ini merupakan penerapan dan konkretisasi dari pengalaman transendental kebebasan (transzendentalen Erfahrung von Freiheit). ${ }^{39}$ Artinya, pengalaman transendental kebebasan terlaksana dan terwujud dalam pengalaman kategorial kebebasan seperti dalam contoh-contoh konkret sehari-hari tersebut. Kebebasan transendental ini bukanlah semacam ringkasan atau kepadatan dari berbagai keputusan penggunaan kebebasan kategorial kita, tetapi merupakan pelaksanaan diri manusia yang paling dalam menurut keterarahannya pada tujuan akhir hidupnya, yakni kepada Allah. ${ }^{40}$ Dengan demikian, dalam pandangan Karl Rahner, kebebasan itu bukan pertama-tama soal keadaan untuk membuat keputusan pilihan ini atau itu, tetapi kebebasan (transendental) itu berkaitan dengan pelaksanaan diri manusia dalam transendentalitasnya, yakni keterarahannya menuju tujuan terakhirnya, yakni kepada Allah. ${ }^{41}$

Kebebasan transendental dan kebebasan kategorial dapat dibedakan tetapi tidak dapat dipisahkan. ${ }^{42}$ Dalam kebebasan kategorial terlak-

39 Karl Rahner, Grundkurs des Glaubens, S. 46.

40 Karl Rahner, Grundkurs des Glaubens, SS. 102-103.

41 Karl Rahner, "Das Christliche Sterben," S. 287.

42 Franz Gmainer-Pranzl, Glaube und Geschichte bei Karl Rahner und Gerhard Ebeling, S. 161. 
sanalah kebebasan transendental yang terarah pada finalitasnya kepada Allah, entah dalam arti pengiayaan ataupun penolakan kepada-Nya. Dalam pelaksanaan kebebasannya itu, manusia tidak pernah dapat melepaskan diri dari relasi dan pengaruhnya dari sesama dan dunia lingkungannya. Artinya, pelaksanaan kebebasan setiap orang selalu tidak dapat terpisahkan dari pelaksanaan kebebasan orang lain dan bahkan seluruh sejarah umat manusia. Begitu pula dalam misteri kesalahan dan dosa, tidak ada seorang pun manusia di dunia ini yang hidup bagaikan di sebuah pulau yang terpisah, karena bagaimanapun juga setiap orang tidak pernah dapat terlepas dari kesalahan dan dosa sesama ataupun lingkungannya, entah langsung ataupun tidak langsung. ${ }^{43}$ Ada suatu objektivasi kesalahan dan dosa umat manusia yang tak terelakkan pada hakikat diri setiap manusia. ${ }^{44}$ Karl Rahner mengatakan bahwa dalam pengalaman hidup kita sebagai manusia ini ada segi kehidupan yang penuh kegelapan dan tak terpahami, yaitu dosa-kesalahan umat manusia. ${ }^{45}$ Kita berada dan masuk dalam sejarah kemanusiaan yang diliputi kegelapan dosa dan kesalahan yang tidak kita mengerti, karena secara pribadi tidak kita lakukan tetapi kita kena dampak sekaligus juga terlibat di dalamnya.

Universalitas dan ketidakterelakkannya kepastian dosa-kesalahan yang melingkungi situasi kebebasan dalam sejarah kemanusiaan inilah yang oleh Rahner dikaitkan dengan ajaran Gereja mengenai dosa asal. ${ }^{46}$ Rahner tentu tetap berpijak pada ajaran Gereja tentang dosa asal, hanya saja ia memberi penjelasan tentang hal ini dalam terang pandangannya mengenai rahmat sebagai pemberian diri Allah (Selbsmitteiling Gottes). ${ }^{47}$ Dosa asal tidak dipikirkan sebagai tindakan dosa personal manusia pertama, dalam arti tindakan moral manusia pertama, yang seolah kemudian dibebankan atau beralih pada diri kita umat manusia keturunannya. ${ }^{48}$ Maka dosa asal itu lebih menunjuk pada keadaan dosa dan bukan perbuatan dosa yang seolah setiap manusia (sebagai keturunan

43 Karl Rahner, Grundkurs des Glaubens, S. 115.

44 Karl Rahner, Grundkurs des Glaubens, S. 114.

45 Karl Rahner, Über die Sakramente der Kirche. Meditation, S. 85.

46 Karl Rahner, Grundkurs des Glaubens, S. 116.

47 Karl Rahner, Grundkurs des Glaubens, SS. 118-120.

48 Karl Rahner, Grundkurs des Glaubens, S. 117. 
Adam) ikut melakukannya. ${ }^{49}$ Di satu pihak pemberian diri Allah kepada manusia dan dunia bersifat "sudah ada diberikan" (vorgegeben), artinya melekat pada hakikat diri (das Wesen) dan adanya (Dasein) setiap manusia, lepas dari dosa Adam; di lain pihak pemberian diri Allah itu tidak pernah mencabut kebebasan manusia. Bahkan manusia dapat menyadari bila memiliki kebebasan pun justru berkat pemberian diri Allah itu. Rahner berpikir tentang dosa asal itu dengan menggunakan dua dasar: pertama: dasar dari universalitas kepastian dosa-kesalahan yang melingkupi situasi kebebasan setiap manusia itu; dan kedua: dasar dari sejarah pewahyuan dan keselamatan Allah yang berupa pemberian diri Allah ke dalam sejarah manusia dan dunia ini, dalam mana Allah tetap memberikan kebebasan kepada manusia untuk menolak atau berkata "tidak" terhadap tawaran pemberian diri Allah tersebut. ${ }^{50}$

Pandangan Rahner yang sangat penting tentang dosa asal dengan demikian diletakkan dalam konteks sejarah keselamatan Allah yang merupakan pemberian diri Allah yang berpuncak pada Allah-Manusia, Yesus Kristus. Bagi Rahner, dosa asal menunjuk kepastian dosa-kesalahan umat manusia yang melingkupi situasi kebebasan (transendental) setiap manusia, yang pertama-tama tidak dilihat atau tidak berpangkal tolak dari "dosa Adam," melainkan justru dari sudut tujuan dari sejarah manusia dan dunia, yakni puncak sejarah keselamatan Allah pada diri Yesus Kristus. ${ }^{51}$ Demikianlah dalam teologi Karl Rahner, dosa asal dijelaskan dari sudut pangkal tolaknya pada Yesus Kristus yang menjadi puncak dari pemberian diri Allah kepada umat manusia dan dunia. Justru karena Yesus Kristus sebagai puncak pemberian diri Allah datang dan menebus dosa manusia, kita lalu mengenal adanya dosa asal.

Dosa asal ini tentu saja telah dihapuskan oleh penebusan Yesus Kristus, dan rahmat penebusan Kristus yang menghapus dosa asal itu diterima setiap orang kristiani melalui Sakramen Baptis. Seperti halnya pengajaran Gereja Katolik, Rahner juga menyebut konkupisensi sebagai keinginan yang tak teratur sebagai akibat dosa asal, yang tetap ada pada

49 Bdk. Katekismus Gereja Katolik no. 404-405.

50 Karl Rahner, Grundkurs des Glaubens, SS. 119-120.

51 Karl Rahner, Grundkurs des Glaubens, S. 120. 
diri setiap orang setelah penerimaan baptisan. ${ }^{52}$ Dosa sendiri, dalam arti dosa pribadi, selalu dipahami Rahner sebagai suatu pelaksanaan kebebasan transendental yang melawan Allah melalui bentuknya yang kategorial, historis dan fragmentaris. ${ }^{53}$ Itulah berbagai dosa-kesalahan yang dilakukan seseorang dengan kehendaknya yang bebas. Yang khas dalam pembahasan Rahner tentang tema dosa-kesalahan adalah penjelasannya mengenai ketakdapat-terhapusnya kesalahan-dosa oleh diri manusia sendiri (die Unaufhebbarkeit der menschlichen Schuld durch den Menschen allein). ${ }^{54}$ Ketakdapat-terhapusnya dosa-kesalahan oleh diri manusia sendiri ini tentu saja ada dalam pengandaian ajaran Gereja mengenai dosa-kesalahan sebagai tindakan bebas manusia yang melawan kasih Allah dan sekaligus pengampunan dosa manusia itu oleh Allah sendiri..$^{55}$

Ketakdapat-terhapusnya kesalahan-dosa oleh diri manusia sendiri tidak boleh dimengerti menurut model hukum sipil. ${ }^{56}$ Dalam norma hukum sipil, orang yang melakukan kesalahan dan apalagi berakibat buruk kepada orang lain, seperti misalnya pencurian, perampokan dan apalagi pembunuhan, entah disengaja atau tidak disengaja, akan tetap menerima hukuman sesuai dengan kesalahannya itu. Atau orang yang melakukan pelanggaran terhadap suatu peraturan perundangan di masyarakat tentu juga akan dituntut suatu hukuman atau denda tertentu. Contoh yang amat sering ialah pelanggaran lalu lintas atau pelanggaran pajak. Hukuman tersebut tetap akan diberikan oleh lembaga yang berwenang, meskipun barangkali saja orang yang bersangkutan telah menyesali perbuatannya. Rasa penyesalan atas perbuatan yang telah dilakukan tentu saja suatu awal pertobatan yang baik, tetapi kesalahan dosa orang tersebut tetap belum dapat dihapuskan oleh diri sendiri. Poinnya bukan hanya rasa bersalah yang barangkali terus menghantui orang yang telah menyesali perbuatan dosanya itu saja, tetapi orang

52 Kompleksitas tema konkupisensi dibahas khusus oleh Rahner dalam artikel "Zum theologischen Begriff der Konkupiszenz," Schriften zur Theologie I, SS. 377-414.

53 Karl Rahner, Grundkurs des Glaubens, S. 121.

54 Karl Rahner, Über die Sakramente der Kirche. Meditation, S. 93.

55 Karl Rahner, "Reconciliation and Vicarious Representation," dalam Theological Investigation XXI, p. 257.

56 Karl Rahner, “Reconciliation and Vicarious Representation,” pp. 257-258. 
memang sungguh menghadapi misteri kegelapan hidup yang tak dapat dimengerti..$^{57}$

Alasan pokok mengapa manusia tidak dapat menghapus dosakesalahannya sendiri terletak pada sifat dialogis yang khas dari eksistensi manusiawi dalam hubungannya dengan Allah. ${ }^{58}$ Di sini kembali pada pokok teologi transendental Rahner bahwa dari hakikatnya manusia itu hidup, ditopang dan dilandasi oleh pemberian diri Allah. Entah menyadari atau tidak, Allah sudah dan selalu memberikan diri-Nya kepada manusia, terlepas entah bagaimana manusia menanggapinya. Dialog itu terjadi antara Allah dan manusia, dalam mana Allah selalu terlebih dahulu telah memberikan diri-Nya kepada manusia, dan sekaligus manusia berada dalam kebebasan dasar (kebebasan transendental) yang memungkinkan dia (manusia) untuk menanggapi, entah secara positif (mengiyakan) ataupun negatif (menolak), pemberian diri Allah yang sudah melekat-ada dan intrinsik di dalam dirinya itu. Dengan demikian sebenarnya akhirnya manusia hanya dapat menyesali atau menyadari dosa-kesalahannya selalu saja karena diterangi oleh pemberian diri Allah yang sudah dialami dalam diri manusia itu. Dari hakikatnya, manusia tidak pernah dapat melepaskan diri dari Allah, juga kalau manusia melawan Allah (artinya berbuat dosa). Jelaslah dari dirinya sendiri manusia tidak pernah dapat menghapuskan dosa-kesalahannya, pertama karena seluruh kemampuan dan kesadaran manusia selalu hanya ditopang oleh Allah, sehingga ia selalu membutuhkan Allah, dan kedua karena dosa-kesalahan sebagai tindakan bebas dari manusia itu selalu saja dalam kaitan tanggapan relasinya dengan Allah, sehingga ia membutuhkan penghapusan dosa itu dari Allah.

\section{SABDA PENGAMPUNAN ALLAH YANG TAK DAPAT DIPAHAMI}

Justru ketika manusia menyadari bahwa dosa-kesalahannya tidak dapat dihapus atau dihilangkan oleh diri manusia sendiri, maka dari hakikatnya pula manusia merindukan sabda pengampunan Allah (das

57 Bdk. Karl Rahner, Über die Sakramente der Kirche. Meditation, S. 88.

58 Karl Rahner, "Reconciliation and Vicarious Representation," p. 258. 
Wort der Vergebung von Gott) atas dosa-kesalahannya..$^{59}$ Menurut Rahner, sabda pengampunan dari Allah untuk dosa-kesalahan manusia itu tidak pernah dapat dituntut atau dipaksakan oleh manusia kepada Allah, sebab sabda pengampunan dari Allah ini melulu rahmat yang cumacuma, bahkan suatu mukjizat dari kasih Allah sendiri. ${ }^{60}$ Pengampunan dosa melulu merupakan mukjizat kasih Allah sendiri, sebab di sini Allah memberikan diri-Nya sendiri kepada manusia yang setiap harinya terus memberontak dan melawan diri-Nya. Manusia tidak berhak tetapi nyatanya pengampunan dosa itu sudah selalu diberikan oleh Allah. Dalam arti inilah mengapa sabda pengampunan Allah itu sungguh tidak dapat dipahami.

Sabda pengampunan Allah memang sungguh tidak dapat dipahami sebab hakikat hidup manusia sudah selalu ditopang atau dilandasi oleh pemberian diri Allah yang adalah juga sabda pengampunan-Nya. Manusia nyatanya dapat bersalah dan berdosa, saat ia menggunakan kebebasannya untuk melawan Allah, entah berat atau ringan. Tetapi dari pengalaman dasar manusia harus kita akui juga bahwa dosa-kesalahan yang pernah kita buat tidak pernah dapat kita lupakan begitu saja. Ingatan akan dosa-kesalahan itu tetap membekas dalam perjalanan sejarah hidup kita. Kita boleh saja melupakan dosa-kesalahan kita, tetapi nyatanya kita harus mengakui bahwa dosa-kesalahan itu tetap ada karena memang telah terjadi. Menurut Rahner, justru di situlah manusia memerlukan "sesuatu" sebagai tindakan dari luar dirinya, yang tidak lain adalah sabda pengampunan dosa dari Allah. ${ }^{61}$ Dan Allah memang meminta manusia untuk memiliki pengharapan atas sabda pengampunan-Nya.

Kasih Allah yang mau mengampuni dosa kita memang sungguh tidak dapat dipahami. Menurut Rahner, kita diperbolehkan untuk berkata bahwa Allah mengijinkan dosa-kesalahan ini masuk ke dalam dunia hanya karena dunia ini sejak awal mula secara tak dapat ditarik kembali telah diisi atau dipenuhi dengan kasih pengampunan dan pendamaian

59 Karl Rahner, Über die Sakramente der Kirche. Meditation, S. 98.

60 Karl Rahner, Grundkurs des Glaubens, SS. 405-406.

61 Karl Rahner, “Reconciliation and Vicarious Representation,” p. 260. 
dari Allah melalui pemberian diri-Nya itu. ${ }^{62}$ Sejak awal mula, Allah telah membuat diri-Nya berada dalam dunia ciptaan-Nya untuk secara sukarela hati-Nya ditembus atau ditusuk oleh dosa-kesalahan manusia, karena justru karena hati-Nya adalah hati yang penuh belas kasih, yakni kasih pengampunan dan pendamaian. Tentu saja orang dapat tetap dihukum pada pengadilan terakhir apabila orang itu tetap menolak sabda kasih pengampunan Allah hingga pada tindakan final dari kebebasannya.

Rahner menjelaskan lebih lanjut mengenai keagungan sabda pengampunan Allah itu. Sabda pengampunan dosa dari Allah ini bukan hanya datang kemudian sesudah orang menyesal atau bertobat, yakni yang diberikan oleh Allah sebagai anugerah, tetapi juga sudah menjadi penggerak dan pendorong yang memungkinkan seseorang itu ingin menyesal dan bertobat atas kesalahan dosanya. Mengapa? Ya karena hakikat dan keberadaan manusia selalu saja ditopang oleh pemberian diri Allah. Dalam seluruh sejarah kemanusiaan, sabda pengampunan Allah ini, yang merupakan pemberian diri Allah sendiri, sebenarnya selalu ada dan telah diberikan, hanya saja masih implisit, sehingga manusia tidak selalu dapat menyadarinya.

Sabda pengampunan Allah yang ada dan melekat dalam sejarah kemanusiaan itu memang tersembunyi dan tidak dikenal manusia. Meskipun begitu manusia dapat mendengar sabda pengampunan dosa dari Allah itu lewat suara hatinya. ${ }^{63}$ Hanya saja itu tidak selalu jelas. Tetapi akhirnya Allah menyatakan sabda pengampunan-Nya itu secara eksplisit, yakni dalam sejarah keselamatan Allah yang dimulai dengan panggilan Israel dalam Perjanjian Lama. Dan akhirnya sabda pengampunan Allah itu mengalami puncak pernyataan dan pelaksanaannya, dan sekaligus sebagai peristiwa yang sekali untuk selamanya, alias final dan tak dapat ditarik kembali (unwiderruflich), pada Yesus Kristus. Dalam peristiwa wafat dan kebangkitan Kristus, sabda pengampunan Allah itu terlaksana melalui solidaritas Allah-Manusia yang karena kasih-Nya mau masuk ke dalam hukuman umat manusia, yakni maut, dan sekaligus di dalam

62 Karl Rahner, “Reconciliation and Vicarious Representation,” pp. 260-261.

63 Karl Rahner, Über die Sakramente der Kirche. Meditation, S. 99. 
tindakan terakhirnya dari iman, harapan dan kasih-Nya yang memasuki kegelapan kematian dan mengalami kegelapan akibat dosa-kesalahan kita, sabda pengampunan Allah itu diterima bagi kepentingan kita umat manusia. $^{64}$

Demikianlah sabda pengampunan Allah yang tak dapat dipahami oleh karena begitu agung, dahsyat dan dalamnya itu telah menjadi eksplisit dan mencapai kulminasi pelaksanaannya bagi hidup seluruh umat manusia melalui Yesus Kristus. Kasih pengampunan Allah yang tak terbayangkan itu dinyatakan dalam salib Kristus. Dalam peristiwa salibNya, Yesus Kristus menjadi pendamaian Allah dengan manusia, manusia dengan Allah. Dari pihak Allah, Kristus menyatakan kasih pengampunan Allah Bapa yang tak terbatas itu kepada umat manusia. Dan dari pihak manusia, kasih pengampunan Allah Bapa itu diterima secara penuh dengan segala kebebasannya oleh manusia melalui Kristus. Artinya, Kristus sebagai Allah-Manusia menjadi puncak dan titik temu antara tawaran sabda pengampunan dari pihak Allah itu dan penerimaannya oleh manusia. Justru di sinilah keagungan misteri salib Kristus. Sebab dalam misteri salib Kristus itu, Allah tidak hanya menawarkan kepada manusia kasih pengampunan-Nya yang mengatasi dan menghapus dosa-kesalahan manusia, tetapi juga Allah mewahyukan diri-Nya bahwa sabda kasih pengampunan dosa yang begitu tak terbatas itu begitu berdaya dan mencapai kemenangan jaya yang tak dapat ditarik kembali atas dosa manusia justru ketika sabda pengampunan itu diterima dengan kebebasan manusia. ${ }^{65}$ Demikianlah sabda pengampunan Allah baru menjadi realitas yang penuh ketika telah diterima oleh manusia dengan kebebasannya.

\section{ANEKA BENTUK KEHADIRAN SABDA PENGAMPUNAN ALLAH DALAM GEREJA}

Sabda pengampunan Allah yang berpuncak dalam misteri wafat dan kebangkitan Kristus itu kini tetap hadir dalam Gereja. Karena Gereja adalah tanda kehadiran Kristus secara historis-sosial di dunia 64 Karl Rahner, Grundkurs des Glauben, S. 406.

65 Karl Rahner, “Reconciliation and Vicarious Representation," p. 261. 
ini, maka Gereja juga menjadi sakramen dasar dari sabda pengampunan Allah ini bagi manusia. ${ }^{6}$ Penjelasan ini berada dalam skema pemikiran sakramental Karl Rahner yang selalu menempatkan Gereja sebagai sakramen dasar (Grundsakrament) dari Yesus Kristus yang adalah sakramen induk (Ursakrament). Melalui Gereja, sabda pengampunan Allah yang berpuncak dan mengalami kepenuhan dalam diri Yesus Kristus itu dihadirkan kepada setiap orang di dunia ini melalui banyak bentuk dan cara.

Rahner menyebut berbagai bentuk dan cara kehadiran sabda pengampunan Allah itu melalui Gereja bagi manusia. ${ }^{67}$ Sabda pengampunan Allah diwartakan sebagai kabar baik melalui rumusan Syahadat Para Rasul: "Aku percaya.....pengampunan dosa." Dengan pengakuan iman tersebut, Gereja mewartakan bahwa sabda pengampunan Allah atas dosa-dosa manusia sungguh ada dan terlaksana, yakni melalui Yesus Kristus. Sabda pengampunan Allah itu juga dihadirkan secara mendasar dan efektif di sepanjang sejarah kepada setiap orang melalui sakramen baptis. Sebab dengan baptisan, setiap orang menerima sabda pengampunan Allah yang menghapus seluruh dosa orang itu, termasuk dosa asal. Sabda pengampunan Allah juga hadir dan berdaya efektif dalam doa Gereja, saat Gereja berdoa untuk dirinya sendiri, mengingat Gereja adalah Gereja yang berdosa, dan juga untuk setiap anggotanya yang selalu membutuhkan belas kasih Allah. Gereja juga memohon sabda pengampunan Allah melalui doanya bagi pertobatan manusia dan bagi pendampingan para warganya ataupun setiap orang pada saat kematiannya.

Cara yang sangat khusus dan istimewa bagaimana sabda pengampunan Allah itu dihadirkan bagi setiap orang kristiani adalah melalui sakramen tobat atau sakramen rekonsiliasi ${ }^{68}$ Dalam alur pemikiran sakra-

66 Karl Rahner, Über die Sakramente der Kirche. Meditation, S. 99.

67 Karl Rahner, Über die Sakramente der Kirche. Meditation, S. 100.

68 Dalam tulisan bahasa aslinya, yakni dalam bahasa Jerman, Rahner biasa menggunakan istilah sakramen tobat (Bußsakrament), tetapi dalam bahasa Inggris, sakramen tobat ini juga diterjemahkan dengan sakramen rekonsiliasi. Jadi tampaknya kedua istilah: sakramen tobat ataupun sakramen rekonsiliasi digunakan dengan sadar oleh Karl Rahner. Lihat kedua sumber: Über die Sakramente der Kirche. Meditation dan "Reconciliation and Vicarious Representation." Dalam kedua sumber tersebut, Karl Rahner memberikan kata pengantar sendiri. Dalam Theological Investigation XXIII, 
mental Karl Rahner sebagaimana sudah disebut di atas, maka sakramen tobat merupakan konkretisasi pelaksanaan sabda pengampunan Allah yang berpuncak dalam Yesus Kristus melalui pelayanan Gereja kepada setiap pribadi orang kristiani. Dengan sakramen tobat ini, sabda pengampunan Allah dianugerahkan kepada orang kristiani yang bertobat melalui Gereja secara khusus. Yang khas dan istimewa dalam sakramen tobat ialah bahwa sabda pengampunan Allah itu dinyatakan atau disampaikan kepada orang yang bertobat ini bukan hanya sebagai suatu pernyataan yang secara eksplisit diucapkan oleh imam sebagai wakil Gereja, tetapi sebagai suatu peristiwa sakramental. ${ }^{69}$ Sabda pengampunan Allah yang disampaikan secara sakramental berarti bahwa apa yang diucapkan (absolusi) melalui Gereja yang diwakili oleh seorang imam itu sungguh terjadi secara real-nyata, berdaya ubah, karena sabda pengampunan Allah itu hadir dan efektif membersihkan dosa orang kristiani itu.

Orang kristiani yang melakukan dosa, entah dosa besar ataupun dosa ringan, telah melukai bukan hanya Allah tetapi juga Gereja sebab ia adalah warga Gereja. Demikianlah perbuatan dosa bukanlah sekedar soal melawan kasih Allah saja, tetapi juga bersifat melukai Gereja sebagai tubuh Kristus. Maka pendamaian yang terjadi dalam sakramen tobat bukan hanya pendamaian orang yang bertobatitu dengan Allah saja, tetapi juga dengan Gereja. Karl Rahner menekankan arti penting pendamaian seorang umat beriman dengan seluruh tubuh Kristus, yakni Gereja, berkat sabda peng-ampunan Allah yang diterima dalam sakramen tobat ini. ${ }^{70}$ Tekanan ini tampak dengan ajaran Konsili Vatikan II yang menyatakan: “Mereka yang menerima sakramen tobat memperoleh pengampunan dari belas-kasihan Allah atas penghinaan mereka terhadap-Nya, sekaligus mereka didamaikan dengan Gereja, yang telah mereka lukai dengan berdosa, dan yang membantu pertobatan mereka dengan cinta kasih, teladan serta doa-doanya" (LG 11). Rahner cukup heran bahwa digunakan pula penerjemahan Sacrament of Reconciliation untuk tulisan Rahner yang aslinya menggunakan istilah Bußsakrament. Hanya saja buku terjemahan yang terakhir ini (T.I. XXIII) baru diterbitkan tahun 1992, tanpa Kata Pengantar dari Karl Rahner karena ia sudah wafat tahun 1984.

69 Karl Rahner, Grundkurs des Glaube, S. 407.

70 Karl Rahner, “Das Sakrament der Busse als Wiederversöhnung mit der Kirche," dalam Schriften zur Theologie VIII, SS. 447-471. 
pada masa sebelum Vatikan II para teolog (dan bahkan pakar sejarah sakramen) tidak menyebut atau bahkan menolak dimensi eklesial atau pendamaian dengan Gereja pada sakramen tobat ini. ${ }^{71}$ Rahner menunjuk sejarah sakramen tobat, khususnya sejak abad pertengahan hingga praVatikan II, yang sangat didominasi oleh paham yuridis dengan tekanan aspek pengadilan. ${ }^{72}$ Padahal menurut Rahner yang didukung oleh banyak teolog besar dari Konsili Vatikan $\mathrm{II}^{73}$ pendamaian orang berdosa dengan Gereja merupakan kunci pemahaman atas sakramen tobat pada masa Gereja abad-abad pertama. ${ }^{74}$

Di sinilah sabda pengampunan Allah yang berpuncak pada wafat dan kebangkitan Kristus dihadirkan Gereja secara khusus melalui sakramen tobat, saat seorang kristiani yang bertobat atas dosa-dosanya kembali didamaikan dengan Allah dan dengan diri Gereja.

\section{BEBERAPA ASPEK SABDA PENGAMPUNAN ALLAH DALAM SAKRAMEN TOBAT}

Segi pendamaian dengan Allah dan Gereja yang dialami oleh orang kristiani yang bertobat dan menerima sabda pengampunan Allah melalui sakramen tobat telah disebut di atas. Dalam hal ini Rahner memiliki penjelasan tambahan berkaitan dengan dasar sakramen tobat, mengapa Gereja berwenang untuk menghadirkan sabda pengampunan Allah yang kulminasi pelaksanaannya terjadi pada wafat dan kebangkitan Kristus.

Rahner menyebut pengetahuan umum tentang dasar biblis untuk kuasa Gereja dalam memberikan pengampunan dosa pada teks Mat. 16:18 dan 18:18 daripada Yoh. 20.75 Menurut Rahner, kuasa Gereja 71 Karl Rahner, "Das Sakrament der Busse als Wiederversöhnung mit der Kirche," SS. $447-448$.

72 Karl Rahner, "Problems concerning Confession," dalam Theological Investigation III, SS. 190-206, di sini SS. 194-196.

73 Karl Rahner, "Das Sakrament der Busse als Wiederversöhnung mit der Kirche," SS. $449-450$.

74 Rahner menulis sejarah sakramen tobat pada masa Gereja abad-abad pertama secara luar biasa dan mendalam, sebagaimana diterbitkan dalam Schriften zur Theologie XI yang berjudul Frühe Bußgeschichte (Sejarah [sakramen] Tobat Awal), setebal 512 halaman.

75 Karl Rahner, "Vergessene Wahrheiten über das Bußsakrament," dalam Schriften zur Theologie II, SS. 143-183, di sini S. 148. 
dalam penghadiran sabda pengampunan dosa melalui sakramen tobat ini dapat difokuskan pada perkataan "mengikat" dan "melepaskan" dari teks biblis: "...apa yang kamu ikat di dunia ini akan terikat di surga dan apa yang kamu lepaskan di dunia ini akan terlepas di surga" (Mat. 18:18). Umumnya orang memahami kata kerja "mengikat" di situ dalam pengertian yuridis, yakni tentang pendosa yang bertobat tetapi belum dapat diberi absolusi karena masih hidup dalam keadaan (status) dosa, seperti kasus: orang yang hidup dalam pernikahan yang tidak sah secara gerejani, sehingga bila ia pergi ke kamar pengakuan, ia belum boleh diberi absolusi yakni sebelum pernikahannya dibereskan secara gerejani. Menurut Rahner, pemahaman yuridis atas kata "mengikat" seperti itu tidak sesuai dengan praktek Gereja abad-abad pertama. ${ }^{76}$

Dalam konteks Gereja abad-abad awal, Rahner menyatakan bahwa kata "mengikat" dan "melepaskan" bukanlah dua pilihan alternatif: atau menolak atau memberikan absolusi, melainkan lebih merupakan dua tahap dari satu proses tanggapan Gereja atas warganya yang sedang memohon sabda pengampunan Allah. ${ }^{77} \mathrm{Hal}$ ini dapat dipahami sebagai berikut: dengan dosanya, seorang kristiani telah melukai (atau bahkan melawan) Allah dan Gereja, sehingga dengan dosanya itu seorang kristiani seperti sudah "berseberangan" atau menempatkan diri "di luar" Gereja, meskipun secara resmi (kecuali telah diekskomunikasi) ia masih warga Gereja. Ketika pendosa itu bertobat, maka Gereja memproses untuk penerimaan sabda pengampunan Allah itu melalui tindakan: pertama: mengikat, yakni menarik kembali orang "yang tadi berseberangan" itu ke dalam diri Gereja, dikhususkan untuk men-jalani penitensi sesuai yang diberikan oleh pemimpin Gereja. Dengan penitensi itu, seorang pentobat dibina dan didampingi Gereja untuk berproses meninggalkan perbuatan dosanya. Dan sesudah ia selesai menjalankan penitensi itu (untuk sekian lama waktu tertentu), Gereja melakukan tindakan kedua: melepaskan dosa orang tersebut, artinya menganugerahkan sabda pengampunan Allah itu melalui pelayanan Gereja.

76 Karl Rahner, "Vergessene Wahrheiten über das Bußsakrament," SS. 149-150.

77 Karl Rahner, "Vergessene Wahrheiten über das Bußsakrament," SS. 150-152. 
Rahner membedakan antara pengampunan eksistensial dan pengampunan sakramental. Keduanya dapat dibedakan tetapi tidak dapat dipisahkan. ${ }^{78}$ Menurut Rahner, orang yang sungguh menyesali dosa dan bertobat, kecuali untuk kasus dosa berat, serta tidak melakukan dosa itu lagi, meskipun ia belum menerima sakramen tobat, orang tersebut dapat secara eksistensial menerima sabda pengampunan Allah atas dosadosanya. Akan tetapi secara gerejawi-resmi, orang tersebut tetap perlu menerima sabda pengampunan Allah itu secara sakramental, yakni melalui sakramen tobat. Rahner menyebut dua jenis pengampunan itu bukan dua peristiwa yang terpisah tetapi mesti dilihat sebagai satu kesatuan peristiwa sabda pengampunan Allah. "Tanda sakramental mesti mewujudkan secara inkarnatoris-eklesial apa yang secara batineksistensial berlangsung dalam diri orang yang bertobat itu." ${ }^{\prime 9}$ Tanda sakramental itu tidak lain ialah sakramen tobat. Dari sini tampak keistimewaan pelayanan sakramen tobat sebagai pelaksanaan sabda pengampunan Allah yang terjadi secara badaniah-manusiawi (bodily expression $)^{80}$ dari apa yang berlangsung secara batin atau dalam hati kita.

Selain menjadi pelaksanaan badaniah-manusiawi sabda pengampunan Allah melalui Kristus dalam pelayanan Gereja, sakramen tobat juga memberikan makna pengampunan dosa itu menurut dimensi sosialnya. Sebagaimana sudah disebut bahwa sakramen tobat tidak hanya mendamaikan kita dengan Allah tetapi juga dengan Gereja, begitu pula sakramen tobat ini memberi bobot sisi sosial dari pengampunan dosa. Pengampunan dosa melalui sakramen tobat sungguh mendamaikan orang dengan sesamanya manusia. Dosa tidak hanya merusak hubungan dengan Allah ataupun diri sendiri, tetapi juga dengan Gereja dan sesamanya. Karl Rahner menyadari dengan baik dimensi eklesial-sosial dari sakramen tobat ini.

Rahner sering membicarakan tentang seberapa perlu dan sering sakramen tobat ini mesti diterima oleh seorang kristiani. ${ }^{81}$ Jadi ini

78 Karl Rahner, "Zur Situation des Bußsakramentes," dalam Schriften zur Theologie XVI, SS. 418-437, di sini SS. 429-430. Artikel ini juga dapat dibaca dalam bahasa Inggris, dengan judul: "The Status of the Sacrament of Reconciliation," dalam Theological Investigation XXIII, SS. 205-218.

79 Karl Rahner, “Zur Situation des Bußsakramentes,” S. 430.

80 Karl Rahner, "The Status of the Sacrament of Reconciliation," p. 214.

81 Selain pada artikel yang sudah disebut, seperti "Zur Situation des Bußsakramentes," 
masalah frekwensi mengaku dosa dalam kamar pengakuan. Hal ini dilatar-belakangi oleh perubahan praktek penerimaan sakramen tobat pada masa pasca-Vatikan hingga pengalaman kita hari ini. Pada masa pra-Vatikan hingga masih awal tahun 1970-an, orang-orang Katolik yang saleh biasa sering pergi ke kamar pengakuan untuk penerimaan sakramen tobat. Itulah yang biasa disebut sebagai pengakuan devosional (confession of devotion). ${ }^{82}$ Orang-orang ini selalu merasa harus pergi ke kamar pengakuan setiap kali akan sambut komuni dalam Misa. Maka pengakuan devosional ini bisa terjadi seminggu sekali atau bahkan dapat setiap hari, yaitu sebelum sambut komuni dalam Misa. Tetapi sejak pertengahan tahun 1970 dan sesudahnya, hingga sekarang, praktek pengakuan devosional seperti ini tidak ada lagi. Kemerosotan penerimaan sakramen tobat dari model pengakuan devosional ini sudah terjadi pada masa tua Karl Rahner, sehingga ia masih menulis dan memberi komentar soal ini. ${ }^{83}$

Menurut Rahner, kemerosotan penerimaan sakramen tobat pada masa pasca-Vatikan II tidak perlu dijadikan masalah, alias tidak perlu disesali. ${ }^{84}$ Bagi Rahner yang terpenting adalah bahwa sakramen tobat sebagai sakramen sabda pengampunan Allah ini tetap hidup dan dihidupi oleh umat beriman. Dari data sejarah ditunjukkan bagaimana bentuk penerimaan sakramen tobat ini berubah-ubah. ${ }^{85}$ Lama dalam sejarah Gereja awal dan zaman Patristik, belum ada yang namanya pengakuan devosional itu; pada waktu itu bahkan sakramen tobat dilaksanakan secara publik dan hanya dibuat sekali seumur hidup. Secara acak misalnya Rahner menyebut bahwa santo Yosef atau santo Agustinus tidak pernah pergi menjalani pengakuan devosional. ${ }^{86}$ Memasuki abad pertengahan,

Rahner juga menulis tentang masalah frekwensi pengakuan dosa pada "Vom Sinn der häufige Andachtsbeichte," "Beichtprobleme" dalam Schriften zur Theologie III, SS. 211-225, 227-245.

82 Karl Rahner, "The Meaning of frequent Confession of Devotion," Theological Investigation III. SS. 177-189.

83 Pada artikel yang sudah disebut: "Zur Situation des Bußsakramentes."

84 Karl Rahner, “Zur Situation des Bußsakramentes," S. 424.

85 Seperti sudah disinggung Rahner menulis satu volume tersendiri yakni Schriften zur Theologie XI yang berbicara tentang sejarah sakramen tobat pada masa awal Gereja.

86 Karl Rahner, "Problems concerning Confession," Theological Investigation III, pp. 190206, di sini 191. 
model pengakuan dosa secara pribadi semakin menggantikan praktek tobat publik itu. Pada Konsili Lateran (th 1215) dimaklumkan peraturan tentang kewajiban seorang kristiani yang melakukan dosa berat secara objektif dan subjektif untuk pergi menerima sakramen tobat kepada seorang imam sekali setahun. ${ }^{87}$ Ajaran ini ditegaskan kembali pada Konsili Trente yang juga menekankan dayaguna sakramen tobat.

Mengapa penerimaan sakramen tobat pasca-Vatikan II tidak lagi sesering dahulu seperti dikenal dengan pengakuan devosional di atas? Rahner menjawabnya dengan berpangkal pada masalah kewajiban pengakuan dosa bagi orang yang berdosa berat secara objektif dan subjektif. ${ }^{88}$ Problemnya ialah manakah yang disebut dosa berat secara objektif dan subjektif itu. Sebagaimana kita ketahui secara umum, dibedakan antara dosa berat dan dosa ringan. Yang diwajibkan untuk menerima sakramen tobat adalah orang yang berdosa berat secara objektif dan subjektif. Secara objektif, perbedaan dosa berat dan ringan cukup mudah dikenali. Seorang yang membunuh orang lain jelaslah melakukan dosa berat, sedangkan orang yang pikirannya ngelantur ke mana-mana selama doa dianggap melakukan dosa ringan. Bagi Rahner, yang terpenting akhirnya apakah dosa berat tersebut dilakukan secara subjektif atau tidak. Bila orang memang menghendaki untuk membunuh sesamanya, jelas orang itu melakukan dosa berat secara objektif dan subjektif. Lain halnya kalau misalnya seorang apoteker yang karena kurang teliti lalu salah memberikan obat kepada seseorang, sehingga berakibat fatal yakni kematian, maka apoteker itu memang dapat dipersalahkan secara objektif (sehingga dapat diproses secara hukum sipil), tetapi secara subjektif apoteker itu tidak berdosa berat karena tidak memiliki kehendak untuk suatu pembunuhan. Begitulah pandangan Rahner. ${ }^{89}$ Tetap baik bahwa apoteker itu menerima sakramen tobat akan tetapi jelas dosa kesalahannya tidak dalam pengertian dosa berat yang subjektif.

87 DS 812. Rahner menyebut konsili ini dalam "Zur Situation des Bußsakramentes," S. 419.

88 Karl Rahner, "Zur Situation des Bußsakramentes," SS. 419-426.

89 Karl Rahner, “Zur Situation des Bußsakramentes," S. 420. 
RELEVANSI TEMA SABDA PENGAMPUNAN DOSA BAGI GEREJA MASA KINI

Di tengah "kemiskinan" tulisan ilmiah mengenai sakramen tobat dalam bahasa Indonesia, kupasan mengenai pemahaman sakramen tobat sebagai sakramen sabda pengampunan Allah dalam teologi Karl Rahner kiranya dapat memberikan penyegaran wawasan kita. Penulis memberikan tiga relevansi pandangan Rahner tentang sakramen tobat ini untuk Gereja Katolik di Indonesia pada masa ini.

Pertama, metode teologi transendental yang digunakan Karl Rahner tentulah bukan satu-satunya metode teologi. Di Indonesia kita mengenal metode teologi kontekstual yang berangkat dari pengalaman konteks masyarakat dengan segala dimensinya. Akan tetapi kekayaan pendekatan Rahner dengan teologi transendentalnya itu terletak pada titik tolaknya yang berangkat dari pengalaman dasar setiap orang, termasuk dalam hal pengalaman akan misteri kegelapan dosa, dan pengalaman akan misteri belas kasih Allah yang tak terbatas. Bagi Rahner, pemberian diri Allah sebagai anugerah sabda pengampunan Allah bersifat mendahului dan menopang seluruh kesadaran dan pengalaman manusia atas kegelapan dosa itu. Berhadapan dengan masyarakat yang cenderung saling menyalahkan, suka dengan penyebaran berita bohong (hoax), serta dosa nafsu berkuasa dan mengejar harta, seorang kristiani perlu bersikap positif, optimis dan berpengharapan bahwa kebaikan akan tetap selalu hadir dan menjiwai masyarakat kita. Itu pula semangat sukacita Injil yang diserukan berkali-kali oleh Paus Fransiskus.

Kedua, sabda pengampunan Allah yang puncaknya terlaksana melalui Kristus dan kini dihadirkan dalam pelayanan Gereja semestinya menjiwai hidup dan cara kesaksian Gereja Katolik di Indonesia. Artinya, berhadapan dengan sikap keras dan sering tak berbelas kasih seperti dari kelompok radikal yang cukup berkembang dalam masyarakat Indonesia, Gereja mesti mewartakan sabda pengampunan Allah itu melalui kesaksian hidup yang penuh pengertian, mendahulukan kasih dan pengampunan, sambil tentu saja meningkatkan dan meluaskan kerja sama dan kolaborasi 
dengan semua elemen masyarakat bagi persaudaraan sejati di Indonesia. Kesadaran sebagai orang-orang yang telah didamaikan dengan Allah melalui misteri salib Kristus kiranya dapat menjadi kesaksian hidup yang damai, seperti doa Santo Fransiskus: "Tuhan jadikanlah aku pembawa damai."

Ketiga, praktek penerimaan sakramen tobat oleh umat di Indonesia yang terjadi umumnya dua kali setahun, yakni saat masa Adven dan masa Prapaskah, sudah pantas disyukuri. Dari pandangan Rahner telah dijelaskan bahwa kemerosotan pengakuan dosa pada masa pascaVatikan II tidak perlu disesali, selain karena kewajiban pengakuan dosa terutama untuk yang berdosa berat secara objektif dan subjektif, juga karena penghadiran sabda pengampunan dosa dapat berlangsung dalam banyak bentuk, meskipun bentuk sakramental melalui sakramen tobat tetaplah khusus dan istimewa. Yang diperlukan kiranya adalah justru katekese tentang kedalaman makna sakramen tobat ini sebagai sabda pengampunan Allah.

Sebagai catatan penutup: sambil berterimakasih kepada Karl Rahner tentang kedalaman makna sakramen tobat sebagai sakramen sabda pengampunan Allah ini, harus penulis katakan bahwa dalam tulisantulisannya Rahner belum menyinggung dan mengembangkan makna dan dimensi ekologis dari pertobatan dan sabda pengampunan Allah ini. Akan tetapi barangkali ini menjadi tugas para teolog kemudian, termasuk para teolog di Indonesia dalam konteks Gereja di Asia dan di Indonesia khususnya.

\section{DAFTAR RUJUKAN}

Dian Permatasari, H. Pengaruh Penghayatan Sakramen Tobat terhadap Penghayatan Tugas Pewartaan Mahasiswa Program Studi Ilmu Pendidikan Kekhususan Pendidikan Agama Katolik USD Yogyakarta. Pdf-skripsi 2009, https:// repository.usd.ac.id/22630/2/051124002_Full.pdf

Gmainer-Pranzl, F. Glaube und Geschichte bei Karl Rahner und Gerhard Ebeling. Ein Vergleich transzendentaler und hermeneutischer Theologie. Innsbruck-Wien: Tyrolia Verlag, 1996.

Indra Sanjaya, V. dan F. Purwanto (ed.). Mozaik Gereja Katolik Indonesia. 50 
Tahun Pasca Konsili Vatikan II. Yogyakarta: Kanisius, 2013.

Kilby, K. Karl Rahner. Terjemahan oleh P. Hardono Hadi. Yogyakarta: Kanisius, 1997.

Kraus, G. “Gnade.” W. Beinert, Lexikon der katholischen Dogmatik. FreiburgBasel-Wien: Herder, 1991, SS. 201-209.

Muhammad Shahid Habib, "Karl Rahner's Thought and His Contribution to the Christian Theology and Philosophy in 20th Century." International Journal of Philosophy and Social-Psychological Sciences 2016, vol. 2 (issue 3), pp. 91-96, tersedia di www.sciarena.com.

Rahner, Karl. “Zum theologischen Begriff der Konkupiszenz." In Schriften zur Theologie I. Zürich-Einsiedeln-Köln: Benziger, 1958, SS. 377-414.

. "Vergessene Wahrheiten über das Bußsakrament." In Schriften zur Theologie II, Zürich-Einsiedeln-Köln: Benziger, 1955. SS. 143-183.

. Kirche und Sakrament, Freiburg: Herder, 1960.

"Vom Sinn der häufige Andachtsbeichte." In Schriften zur Theologie III, Zürich-Einsiedeln-Köln: Benziger, 1964, SS. 211-225; diterjemahkan: "The Meaning of frequent Confession of devotion," Theological Investigation III. London: Darton, Longman\&Todd- New York: Herder and Herder, 1967, pp. 177-189.

. "Beichtprobleme." In Schriften zur Theologie III, ZürichEinsiedeln-Köln: Benziger, 1964, SS. 227-245; diterjemahkan: "Problems concerning Confession," Theological Investigation III, London: Darton, Longman\&Todd- New York: Herder and Herder, 1967, pp. 190-206.

. "Das Sakrament der Busse als Wiederversöhnung mit der Kirche." In Schriften zur Theologie VIII, Zürich-Einsiedeln-Köln: Benziger, 1967, SS. 447-471.

. “Transzendentaltheologie." In K. Rahner dan A. Darlap (ed). Sacramentum Mundi IV, Freiburg-Basel-Wien: Herder, 1969, SS. 986-992.

"Ekklesiologische Grundlegung," In. F.X. Arnold, K. Rahner, V. Schurr, L.M. Weber dan F. Klosterman (ed.). Handbuch der Pastoraltheologie - Band 1, Freiburg-Basel-Wien, 1970, SS. 121-156.

. Frühe Bußgeschichte. In Schriften zur Theologie XI, ZürichEinsiedeln-Köln: Benziger, 1973.

. "Das Christliche Sterben," dalam Schriften zur Theologie XIII, Zürich-Einsiedeln-Köln: Benziger, 1978, SS. 269-304. 
"Zur Situation des Bußsakramentes," dalam Schriften zur Theologie XVI, Zürich-Einsiedeln-Köln: Benziger, 1984, SS. 418437; diterjemahkan: "The Status of the Sacrament of reconciliation." Theological Investigation XXIII, 1992, pp. 205-218. . "Reconciliation and Vicarious Representation." In Theological Investigation XXI, London: Darton, Longman\&Todd New York: Herder and Herder, 1988, pp. 255-269.

Grundkurs des Glaubens: Einführung in den Begriff des Christentums. Freiburg-Basel-Wien: Herder, 1991.

Über die Sakramente der Kirche. Meditation. FreiburgBasel-Wien: Herder, 1991.

Schüssler Fiorenza, F. "Systematic Theology: Task and Methods," dalam F. Schüssler Fiorenza dan John P. Galvin (ed.), Systematic Theology. Roman Catholic Perspectives. Minneapolis: Fortress Press, 1991, pp. 3-87.

Suratman Gitowiratmo, St dan F. Purwanto. Relevansi Pelayanan Pastoral Gereja Keuskupan Agung Semarang dalam Konteks Budaya Hidup Sekularistik. Yogyakarta: Kanisius - Pusat Penelitian dan Pelatihan Teologi Kontekstual Fakultas Teologi - Universitas Sanata Dharma, 2010. 